\title{
Effect of Play Group and Biopsychosocial Factors on the Independence Development of Preschool Children in Surakarta
}

\author{
Iin Tri Marlinawati'), Harsono Salimo²), Bhisma Murti1) \\ ${ }^{1)}$ Masters Program in Public Health, Sebelas Maret University, Surakarta \\ 2)Department of Pediatrics, Dr. Moewardi Hospital, Surakarta
}

\begin{abstract}
Background:The development of children's independence is important for their future competitiveness in the rapidly increasing social changes. Disturbance in the development of children's independence may have a negative future impact in adult life and children become dependent individuals. Efforts are needed to help children develop optimally. Some play groups have been introduced to meet this need in Surakarta, but no studies have been carried out to evaluate its effectiveness. This study aimed to determine the effect of play group on the independence development of preschool children while controlling for the effect of biopsychosocial factors .

Subjects and Method: This was an analyticobservational study using case control design.The study was conducted at 3 kindergartens in Surakarta, Central Java, from February to April 2017. A sample of 120 kindergarten pupils were selected for this study by purposive sampling and random sampling. The dependent variable was independence development. The independent variables were play group participation status, parenting style (autoritarian, democratic, and permissive), parental education, and child age. The data were collected by a set of questionnaire and analyzed by path analysis.

Results: Maternal education $\geq$ Senior High School $(b=8.77$; CI 95\%=1.89 to 15.66; $p=0.012$ ), paternal education $\geq$ Senior High School $(b=9.82 ; 95 \% \mathrm{CI}=2.70$ to $16.93 ; \mathrm{p}=0.007)$, child age $\geq 5$ years old $(b=5.59 ; 95 \% \mathrm{CI}=1.50$ to $9.68 ; \mathrm{p}=0.007)$, participation in play group $(\mathrm{b}=9.45 ; 95 \% \mathrm{CI}=$ 2.20 to $16.71 ; \mathrm{p}=0.011)$, and democratic parenting style $(\mathrm{b}=0.12 ; 95 \% \mathrm{CI}=0.02$ to $0.23 ; \mathrm{p}=0.018)$ increased child independence. Autoritarian parenting style $(b=-0.15 ; 95 \% \mathrm{CI}=-0.26$ to $-0.45 ; \mathrm{p}=$ o.006) and permissiveparenting style $(b=-0.92 ; 95 \% \mathrm{CI}=-0.20$ to $0.01 ; \mathrm{p}=0.092)$ decreased child independence.Participation in play group was determined by democratic parenting style $(b<0.01$; 95\% CI <0.01 to<0.01; $\mathrm{p}=0.039)$, permissive parenting style $(\mathrm{b}=0.01 ; 95 \% \mathrm{CI}-<0.01$ to $<0.01 ; \mathrm{p}=$ $0.131)$, paternal education $\geq$ Senior High $\operatorname{School}(\mathrm{b}=0.25 ; 95 \% \mathrm{CI}=0.10$ to $0.40 ; \mathrm{p}=0.001)$, and child age $\geq 5$ years old $(b=0.18 ; 95 \% \mathrm{CI}=0.09$ to $0.28 ; \mathrm{p}<0.001)$.

Conclusion: Maternal education $\geq$ Senior High School, paternal education $\geq$ Senior High School, child age $\geq 5$ years old, participation in play group, and democratic parenting style, positively and directly affect child independence. Autoritarian parenting style and permissiveparenting style negatively and directly affect child independence.
\end{abstract}

Keywords: play group,parenting style, biopsychosocial factor, independence, development, preschool children

\section{Correspondence:}

Iin Tri Marlinawati. Masters Program in Public Health, Sebelas Maret University, Jl. Ir. Sutami 36 A, Surakarta, 57126, Central Java, Indonesia. Email: iin3marlina@gmail.com.

Mobile: +6285600252256

\section{BACKGROUND}

$\overline{\text { As the year progresses, the competition was }}$ becoming more fierce as followed by rapidly social changing, thereby enhancing the next generation quality which is tenacious, innovative, and self-sufficient must be aware so that they will be able to compete in the society diversity. One of them is by 
improving the quality of human resources continuously and fostering children'sdevelopment as a whole, in an effort to pay attention and optimize it, especially on children's emotional social developmentor children'sindependence (We, 2015).

Independence is one's ability to direct and controlself-feeling in acting and thinking, and do not always depend on others. Independence is an important issue throughout the human life span, because if a person has a self-sufficient independence, he or she becomes more responsible, confident, respectful to others, able to manage their own activities, achieve more, and tend to be more positive and successful in the future, because his tasks can be solved without having to rely on others (Cvencek et al., 2016).

Independence can not arise instaneously, but can come from a mix of processes during development, aiming to form a superior individual, because indespendence can encourage children to be more innovative, creative and proactive. It requires a long process that must be planted early (Dewanggi et al., 2012).

Low independence has a negative impact on children's personalitydevelopment. If the problem is not addressed immediately, the child may experience difficulties at a later stage of development. They will have difficulty adjusting to the environment, not confident, troublesome and always dependent on others. So that the need for opportunities and family support and the surrounding environment, strategies, parenting, and stimulation in accordance with the children'sneeds, so that children's development aspects are achieved optimally, especially in the cultivation of independence (Andriani et al., 2012; Dahl and Lochner, 2012) .

The community and school environments play a major role in the develop- mental stage of child self-sufficiency, namely the preschool age stage (3-6 years) of children have various potentials that must be honed so that the child's development is optimally fulfilled, as they are the nation's assets and must obtain worthy to have a broad knowledge, a noble personality, and can develop their potential. Because the basic capital education prepares the next generation of quality nations, the education should be taught early (Kayode and Olaronke, 2014).

Education that supports the development of early childhood institutions is Early Childhood Education (PAUD). One of them is the Play Group which is the main education foundation whose aims are to facilitate the facilities and infrastructure of children's development as a whole and prioritize the development of the child's personality aspect, so that children have noble character, responsible, independent (Setyaningrum et al., 2014).

The family also plays an important role in the development process of child self-reliance, because the family is the closest to the children, therefore theparent role in educating children is very important. One of them is in fulfilling various basic needs of children, such as physical needs biomedical (ASUH), emotions/ affection (ASIH), and mental stimulation needs (ASAH) that need applying through communication between parents and children that can affectchildren'spersonality and independence quality(Ambarwati et al., 2014; Dewanggi et al., 2012).

Parenting treatment is the key to a nation's success and Demographic Surplus 2020. However, today many wives are working to help their husbands in earning a living to meet family needs. So the time given to train and monitor children's development is not maximal and there are various problems of child development 
Journal of Maternal and Child Health (2017), 2(4): 284-296

https://doi.org/10.26911/thejmch.2017.02.04.01

such as low child self-reliance (Hasibuan and Ekowati, 2016).

Based on the above description, the researchers are interested in conducting study on Play Groups and biopsicosocial factors affectedby the independence of preschoolers. This study aims to analyze the influence of parental authoritarian parenting, democratic parenting, permissive parenting, parental education level, child age, and playgroup on the independence of preschoolers.

\section{SUBJECTS AND METHOD \\ 1. Study Design}

This was an observational analytic study design with a control case approach. The data were collected in 3 kindergartens in Surakarta City around February up to April 2017.

\section{Population and Sample}

The accesible population in this study was all preschoolers in Surakarta. The Total sample of the study was 120 subjects.Then, Purposive sampling technique was applied to determine which district was going to be conducted for this study. They were Laweyan, Banjarsari, and Jebres. Simple random sampling was applied in this study to choose the sample as the representative of the population. Therefore, there were 3 kindergartens chosen in Surakarta as the sample which were TK Kemala Bhayangkari 56, TK Cemara Dua, and TK Aisyiyah Guwosari. Proportional random sampling was applied to determine the proportion of the study subjects.

\section{Study Variables}

This study consisted of seven variables, namely independent variables including authoritarian parenting, democratic, authoritarian, parent's education level, child's age, and playgroup, while the dependent variable including the preschoolers' independence.

\section{Definition of Operational Variables} Authoritarian parenting is the daily treatment which is applied by parent in raising their children by giving very strict rules, often forcing, always using violence when solving the problems without thinking about what the child feels.

Democratic parenting is the daily treatment applied by parents in the process of raising their children by giving the children chance and responsibility based on their capability, and also involving them in making decision. Permissive parenting is daily treatment applied by the parents by giving the children freedom.

Parents'education level is the highest education that have been through by parents to get their last certificate. Children's age is the time since they were new baby born until the study was conducted. The Play Group is a series of educational processes conducted in a sistematically wayto optimize the children's development.

Independence is the abilitybased on theirthe various tasks of child development and can do something without relying on someone'shelp, including the ability to take care of themselves, the ability to socialize with people around, behave towards peers and older people and activeness while studying at school as well as at home.

\section{Study Intruments}

Data collection on this study were taken by giving the quisionnaire. Before that, reliability test of the questionnaire has been done before it was given to take the data. The results of the questionnaire reliability test were presented in Table 1 . Based on Table 1, it showed that the authoritarian parenting, democratic, permissive, and child's independencehad the correlation item $\geq 0.20$ and Alpha Cronbach $\geq 0.70$, so the instrument was reliable and can be used as a guide in implementing study. 
Table 1. Reliability test results

\begin{tabular}{clcc}
\hline No. & \multicolumn{1}{c}{ Variables } & Item Total Correlation (r) & AlphaCronbach \\
\hline 1 & Authoritarian parenting style & $\geq 0.31$ & 0.89 \\
2 & Democratic parenting style & $\geq 0.35$ & 0.87 \\
3 & Permissive parenting style & $\geq 0.31$ & 0.85 \\
4 & Children independence & $\geq 0.31$ & 0.89 \\
\hline
\end{tabular}

\section{Data Analysis}

Data analysis in this study was univariate quantitative data analysis, bivariate, and path analysis. Path analysis was conducted to analyze the direct and indirect effect of exogenous variables toward endogenous variables, and to analyze exogenous variables toward endogenous variables through intermediate variables. Analysis path used the STATA program.

Table 2. Characteristics of study subjects

\begin{tabular}{|c|c|c|}
\hline Characteristics & $\mathbf{N}$ & \% \\
\hline \multicolumn{3}{|l|}{ Authoritarian parenting style } \\
\hline Weak $($ score $<96)$ & 60 & 50 \\
\hline Strong (score $\geq 96$ ) & 60 & 50 \\
\hline \multicolumn{3}{|l|}{ Democratic parenting style } \\
\hline Weak $($ score $<146)$ & 58 & 48.3 \\
\hline Strong (score $\geq 146$ ) & 62 & 51.7 \\
\hline \multicolumn{3}{|l|}{ Permissive parenting style } \\
\hline Weak $($ score $<82.5)$ & 60 & 50 \\
\hline Strong (score $\geq 82.5$ ) & 60 & 50 \\
\hline \multicolumn{3}{|l|}{ Maternal education level } \\
\hline$<$ Senior High School & 53 & 44.2 \\
\hline$\geq$ Senior High School & 67 & 55.8 \\
\hline \multicolumn{3}{|l|}{ Paternal educational level } \\
\hline$<$ Senior High School & 49 & 40.8 \\
\hline$\geq$ Senior High School & 71 & 59.2 \\
\hline \multicolumn{3}{|l|}{ Children's age } \\
\hline$<5$ years old & 35 & 29.2 \\
\hline$\geq 5$ years old & 85 & 70.8 \\
\hline \multicolumn{3}{|l|}{ Kindergarten } \\
\hline Followed & 80 & 66.7 \\
\hline Did not follow & 40 & 33.3 \\
\hline \multicolumn{3}{|l|}{ Children independence } \\
\hline Low $($ score $<83)$ & 65 & 54.2 \\
\hline High (score $\geq 83$ ) & 55 & 45.8 \\
\hline
\end{tabular}

Based on the table 2, it showedthat there were 120 parents who applied a weak and strong authoritarian parenting was 50\% for each. 62 parents applied a strong democratic parenting (51.7\%).There were 60 persons who applied a weak and strong

\section{RESULTS}

The characteristics of the study subjects gave a general description on the distribution of study subjects based on each of the study variables that included authoritarian parenting, democratic parenting, permissive parenting, child's age, playgroup, mother's education level, father's education level, and preschoolers' independence shown in Table 2. 
Journal of Maternal and Child Health (2017), 2(4): 284-296

https://doi.org/10.26911/thejmch.2017.02.04.01

80 (66.7\%), children did not follow Play

had low independent level.

Group, and as many as 65 (54.2\%), children

Table 3. Bivariate analysis of factors affectingchildren'sindependence

\begin{tabular}{|c|c|c|c|c|c|c|c|}
\hline \multirow{3}{*}{ Variables } & \multicolumn{4}{|c|}{ Children Independence } & \multirow{3}{*}{$\mathbf{O R}$} & \multirow{3}{*}{$95 \%$ CI } & \multirow{3}{*}{$\mathbf{p}$} \\
\hline & \multicolumn{2}{|c|}{ Low } & \multicolumn{2}{|c|}{ High } & & & \\
\hline & $\mathbf{n}$ & $\%$ & $\mathbf{N}$ & $\%$ & & & \\
\hline \multicolumn{8}{|c|}{ Authoritarian Parenting } \\
\hline Weak (score<96) & 27 & 45 & 33 & 55 & \multirow[b]{2}{*}{0.47} & \multirow[t]{2}{*}{0.23 too.98 } & \multirow[b]{2}{*}{0.044} \\
\hline Strong (score $\geq 96$ ) & 38 & 63.3 & 22 & 36.7 & & & \\
\hline \multicolumn{8}{|c|}{ Democratic Parenting } \\
\hline Weak (score<146) & 44 & 75.9 & 14 & 24.1 & \multirow{3}{*}{6.14} & \multirow[t]{2}{*}{2.76 to 13.64} & \multirow{2}{*}{$<0.001$} \\
\hline Strong (score $\geq 146$ ) & 21 & 33.9 & 41 & 66.1 & & & \\
\hline \multicolumn{7}{|l|}{ Permissive Parenting } & \\
\hline Weak (score<82.5) & 23 & 38.3 & 37 & 61.7 & \multirow{3}{*}{0.27} & \multirow[t]{2}{*}{0.13 to. 57} & \multirow{2}{*}{$<0.001$} \\
\hline Strong (score $\geq 82.5$ ) & 42 & 70 & 18 & 30 & & & \\
\hline \multicolumn{7}{|c|}{ Mother's Education Level } & \\
\hline Low (<Senior $)$ & 41 & 77.4 & 12 & 22.6 & \multirow{3}{*}{6.12} & \multirow[t]{2}{*}{2.71 to 13.82} & \multirow{2}{*}{$<0.001$} \\
\hline High ( $\geq$ Senior) & 24 & 35.8 & 43 & 64.2 & & & \\
\hline \multicolumn{7}{|c|}{ Father's Education Level } & \\
\hline Low (<Senior $)$ & 40 & 81.6 & 9 & 18.4 & \multirow{2}{*}{8.18} & \multirow[t]{2}{*}{3.42 to 19.56} & \multirow{2}{*}{$<0.001$} \\
\hline High $(\geq$ Senior $)$ & 25 & 35.2 & 46 & 64.8 & & & \\
\hline \multicolumn{8}{|l|}{ Child's Age } \\
\hline Young (<5 years) & 30 & 85.7 & 5 & 14.3 & \multirow{3}{*}{8.57} & \multirow[t]{2}{*}{3.03 to 24.27} & \multirow[b]{2}{*}{$<0.001$} \\
\hline Old ( $\geq 5$ years $)$ & 35 & 41.2 & 50 & 58.8 & & & \\
\hline \multicolumn{7}{|l|}{ Play Group } & \\
\hline Unintended & 52 & 65 & 28 & 35 & \multirow{2}{*}{3.86} & 1.72 to 8.63 & \\
\hline Intended & 13 & 32.5 & 27 & 67.5 & & & 0.001 \\
\hline
\end{tabular}

Table 3 showed bivariate analysis data on the effect of independent variables toward dependent variable, analyzed by imple-menting Chi-Square test and Odds Ratio (OR) calculation with $95 \%$ of confidence level. The results showed that there was a significant correlation between authoritarian parenting $(\mathrm{OR}=0.47 ; 95 \%$ $\mathrm{CI}=0.23$ to $0.98 ; \mathrm{p}=0.044)$; democratic parenting $(\mathrm{OR}=6.14 ; 95 \% \mathrm{CI}=2.76$ to 13.64; $\mathrm{p}<0.001)$; permissive parenting $(\mathrm{OR}=0.27 ; 95 \% \mathrm{CI}=0.13$ to $0.57 ; \mathrm{p}$ $<0.001$ ); mothers' education level (OR = $6.12 ; 95 \% \mathrm{CI}=2.71$ to $13.82 ; \mathrm{p}<0.001)$; fathers' education level $(\mathrm{OR}=8.18$; $95 \% \mathrm{CI}=$ 3.42 to $19.56 ; \mathrm{p}<0.001)$; age of children $(\mathrm{OR}=8.57 ; 95 \% \mathrm{CI}=3.03$ to $24.27 ; \mathrm{p}$ $<0.001)$.Play Group (OR= 3.86; 95\% CI= 1.72 to $8.63 ; \mathrm{p}=0.001)$; and preschoolers' independence.

Figure 1 showed a structural model after estimatingby using IBM SPSS STATA
13 to obtain the result aboveas shown in the figure. The indicator of the suitability of the path analysis model was shown in Table 4 produced the goodness of fit measure, which showed the fit index result with $\mathrm{p}=$ o.202> 0.05 meaning that the empirical model met the specified criteria and expressed empirically.

Table 4 showed that children's independence was influenced by authoritarian parenting, democratic, permissive, parental education, child age, and playgroup. Strong authoritarian parenting patterns decreased the children's independence $(b=-0.15 ; 95 \%$ $\mathrm{CI}=-0.26$ to $-0.45 ; \mathrm{p}=0.006)$. A strong parenting democratic parenting pattern enhanced children's independence $(b=$ $0.12 ; 95 \% \mathrm{CI}=0.02$ to $0.23 ; \mathrm{p}=0.018) . \mathrm{A}$ strong parental permissive parenting pattern can decrease the child's independence $(b=-0.92 ; 95 \% \mathrm{CI}=-0.20$ to $0.01 ; \mathrm{p}$ $=0.092$ ). 
High-educated mother can improve child's independence $(\mathrm{b}=8.77 ; 95 \% \mathrm{CI}=$ 1.89 to $15.66 ; \mathrm{p}=0.012)$. High-educated father improved children's independence $(b=9.82 ; 95 \% \mathrm{CI}=2.70$ to $16.93 ; \mathrm{p}=0.007)$. Children who are $\geq 5$ years increased children's independence $(b=5.59 ; 95 \% \mathrm{CI}=$ 1.50 to 9.68; $\mathrm{p}=0.007$ ). Children who joined the Play Group increased their independence $(\mathrm{b}=9.45 ; 95 \% \mathrm{CI}=2.20$ to $16.71 ; \mathrm{p}=0.011)$.

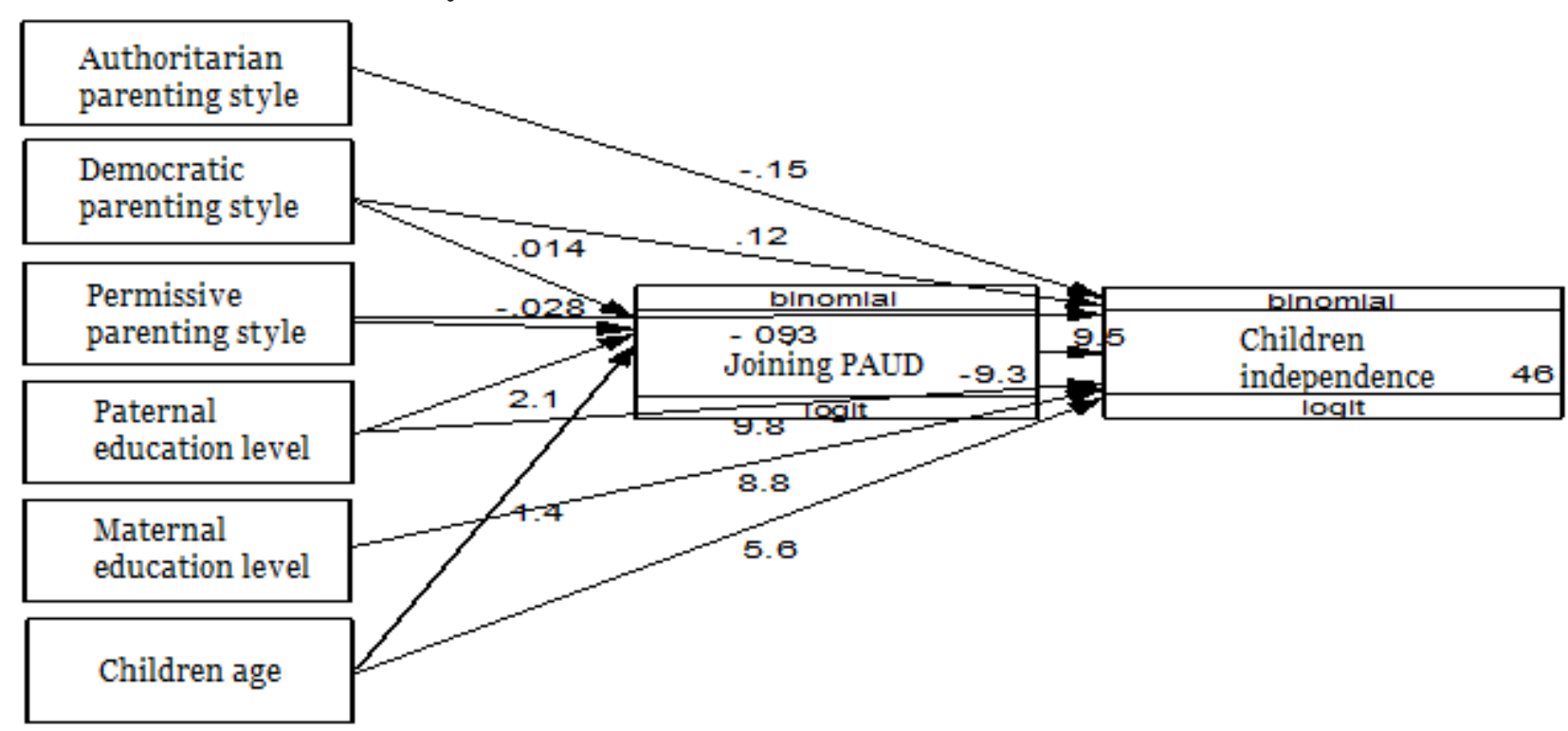

Picture 1. Structural model of path analysis with estimate

Table 4. Path analysis results

\begin{tabular}{|c|c|c|c|c|c|c|}
\hline \multirow[b]{2}{*}{ Dependent Variables } & & \multirow[b]{2}{*}{ Independent Variables } & \multirow[b]{2}{*}{$\mathbf{B}$} & \multicolumn{2}{|c|}{$95 \% \mathrm{CI}$} & \multirow[b]{2}{*}{$\mathbf{p}$} \\
\hline & & & & $\begin{array}{c}\text { Lower } \\
\text { Limit }\end{array}$ & $\begin{array}{l}\text { Upper } \\
\text { Limit }\end{array}$ & \\
\hline Direct Effect & & & & & & \\
\hline Children's Independence & $\leftarrow$ & Strong Authoritarian & -0.15 & -0.26 & -0.45 & 0.006 \\
\hline Children's Independence & $\leftarrow$ & Strong Democratic & 0.12 & 0.02 & 0.23 & 0.018 \\
\hline Children's Independence & $\leftarrow$ & Strong Permissive & -0.92 & -0.20 & 0.01 & 0.092 \\
\hline Children's Independence & $\leftarrow$ & High Mother Education & 8.77 & 1.89 & 15.66 & 0.012 \\
\hline Children's Independence & $\leftarrow$ & High father Education & 9.82 & 2.70 & 16.93 & 0.007 \\
\hline Children's Independence & $\leftarrow$ & Child's Age $\geq 5$ years & 5.59 & 1.50 & 9.68 & 0.007 \\
\hline $\begin{array}{l}\text { Children's Independence } \\
\text { Indirect Effect }\end{array}$ & $\leftarrow$ & Play Group & 9.45 & 2.20 & 16.71 & 0.011 \\
\hline $\begin{array}{l}\text { Indirect Emect } \\
\text { Play Group }\end{array}$ & $\leftarrow$ & Strong Democratic & $<0.01$ & $<0.01$ & $<0.01$ & 0.039 \\
\hline Play Group & $\leftarrow$ & Strong Permissive & $<0.01$ & $<0.01$ & $<0.01$ & 0.131 \\
\hline Play Group & $\leftarrow$ & $\begin{array}{l}\text { Father's Education } \\
\geq \text { Senior High School }\end{array}$ & 0.25 & 0.10 & 0.40 & 0.001 \\
\hline $\begin{array}{l}\text { Play Group } \\
\text { Fit Model } \\
\mathrm{p}=0.202(>0.05)\end{array}$ & $\leftarrow$ & Child's Age $\geq 5$ years & 0.18 & 0.09 & 0.28 & $<0.001$ \\
\hline
\end{tabular}

Table 4 showed the Play Group can be influenced by democratic parenting, permissiveness, father's educational level, and child's age. Children raised with strong democratic parenting seemed more likely to join the Play Group (b <0.01; 95\% CI <0.01 to <0.01; $\mathrm{p}=0.039$ ). Children raised with strong parental permissive parenting were 
Journal of Maternal and Child Health (2017), 2(4): 284-296

https://doi.org/10.26911/thejmch.2017.02.04.01

less likely to join the Play Group (b - <0.01; 95\% CI - <0.01 to <0.01; p $=0.131)$. Children with high-educated fathers were more likely to join the Play Group ( $\mathrm{b}=$ $0.25 ; 95 \% \mathrm{CI}=0.10$ to $0.40 ; \mathrm{p}=0.001$ ). Children who were $\geq 5$ years were more likely to join the Play Group ( $\mathrm{b}=0.18 ; 95 \%$ $\mathrm{CI}=0.09$ to $0.28 ; \mathrm{p}<0.001$ ).

\section{Effect of authoritarian parenting on preschoolers' independence}

Parenting treatment takes an important role to give the children stimulation for their independent development, as parents are the firstfigure to provide basic parenting all about aspects in children's development, which are related to moral, language, psychomotor, independence, and skill (Bukaliya and Mapuranga 2015).

An authoritarian child will have a low self-esteem in her or himself, because authoritarian parents tend to punish, override the children's activities, give less freedom for children to argue and less appreciate children's ideas or feelings, so children become timid, not initiative, like fight and have low self-esteem (Raya et al., 2013).

Based on the results of path analysis in Table 4, it showed that there was a directly negative effect and statistically significant between authoritarian parenting and child's independence. According to Desmita (2015), restrictive parenting, demanding, threating, forcing the parents' will to follow his orders and applying the absolute standards that the child must adhere to can have an impact on the development of child self-sufficiency. The more authoritarian parents, the less independence the child has.

The study results were in line with Seth and Ghormode (2013), Mardliyah et al., (2014), and Mehrinejad et al. (2015) studies that there was a statistically significant effect between authoritarian parenting and child's independence. The autho-ritarian parents tend to punish, gave the children less chance to argue, did not need feedback from children, and overrode every child's activities. The child became less motivated to be able to do the activities independently, always assumed that what he is doing is wrong, was afraid of doing new things, was fear of getting angry and punished by his parents. Children were afraid to express their opinions and did not want to go forward when they were asked to go forward by the teacher at school.

\section{Effect of democratic parenting style on preschooler's indepen- dence}

Taking care of the children by implementing a democratic parenting can foster their sense of responsibility, because they feel comfortable, earn the parents' trust, the rules made are clearly with the logical consequences, the balance of interaction and the wise guidance create a conducive situation. Therefore, it can stimulate the child's independent development (Niez and Alico, 2015).

Based on the results of path analysis in this study, it indicated that there was a directly positive effect and statistically significant influenced between democratic parenting and child's independence. However, there was also a statistically significant influence and indirectly positive effect between democratic parenting on child's independence through the Play Group.

According to Chowdhury and Partners (2015), democratic parenting or parenting that prioritizes the needs of the child, meets the needs of the child based on the child's needs and interest factors. Being responsive to the child and respecting the opinions of the child can affect the independence of the child because the democratic parents are 
rational and acting according to their thought and their children. Be realistic on the child's abilities does not demand the children beyond their capability, and give children chance to choose and act. The children feel cared by their parents, motivated to be creative and explore various things according to their ability and can improve children's independence.

Democratic parents pay more attention to their children, including the development of children's independence. They more appreciate to children's thought and instill trust to their children. One of the actions from parents' trust and attention is by joining their children in an early childhood institutionsuch as a play group, so that children can polish their skills and practice independently. So the more democratic parents are, the higher the independence of the child is, because the child gets stimulated development of learning process in the Playing Group (CevherKalburan, 2014).

The study results were in line with the study conducted by Mehrinejad et al. (2015) and Chemagosi et al. (2016), which were explained that there was a statistically significant and influenced between democratic parenting patterns and child's independence. Parents who adopted democratic parenting had children more independent, more active in the school, pay more attention to education and had a more positive attitude and self-concept, because democratic parents were better recognized the existence of children, gave responsibility to the child gradually according to his ability, firm but full of understanding and warmth, so that children became more independent.

This study also is reinforced by Sunarty and Dirawan (2015) that parental care has a positive and significant influence toward the children's independence. Demo- cratic parenting influences the independence of children, that is, democratic parent with reasoning, understanding, and trust leads to good social behavior in children, so that children have higher independence.

\section{Effect of permissive parenting on the independence of preschoolers}

Permissive parents tend to give children freedom to do things without any supervision, the guidance given to children is minimal, and they are less likely to give warning or rebuke to children when children make mistakes, but they feel warm (Konnie and Alfred, 2013).

Permissive parents believe that unstructured and free expressions can give children the freedom to practice drawing conclusions and expressing values that are understood by themselves. Whereas poor guidance can make the child unaware of what to do, the child has difficulty in understanding the rules for himself and has to learn difficult ways to experiment (Septiari, 2012).

Based on the results of path analysis in this study showed, there was a direct negative influence but not statistically significant between permissive parenting and preschoolers' independence. But there was also a statistically indirect and insignificant non-statistically influence between permissive parenting and child's independence through play groups.

According to Hajiyar and Rezaei (2014), permissive parents have little time for their children, because they are busy for working or taking care of other necessities that result is forgetting their obligation to care for children properly, so that children are only provided with property or material and also letting them grow as they wish. So it triggers a low independence, feels less attention by his parents and spoiled. Permissive parents are also less concerned 
with the development of independence or stimulation of development that their child acquires, such as the stimulation of development that can be obtained through the Play Group.

The study results were in line with studies conducted by Niaraki and Rahimi (2013), Mardliyah et al. (2014) and Mehrinejad et al. (2015) stated that there was non-statistically significant influence between permissive parenting style applied by parents and the independence of children. Parents who were permissive in giving guidance to their children were lacking, so children had difficulty in understanding something, they were easily desperate, and relied more on someone's help. So children did not want to try, did not want to learn for fear of guilt and affected the independence of children, ie children had low self-esteem.

\section{Effect of mother's education level on the independence of preschool children}

Parents' education level affects the acceptance of information, mindset, and applied parenting treatment, because with the experience of education, they will try to give the best for their children. However, the higher the mother's education level effects to the mother's awareness in developing her career. Therefore, mothers who are busy in the career can have an impact on the lack of attention given to their families (Cvencek et al., 2016).

The result of path analysis showed that there was a direct positive and statistically significant influence between maternal education level and child's independence. According to Septiari (2012), the most common and the closest to the child is the mother, so the mother's attitude has a big role to the development of the child, the formation of the child's personalityand the level of independence of the child. The mother's education level can affect the independence of children. Highly educated mothers pay more attention to all changes and every development that happens to the child, then the mother is always trying to find out how to make the child independent. So that highly educated mothers have children who are more independent.

The study results were in line with study conducted by Cvencek et al. (2016), explaining that highly educated mothers have children who are more independent. Highly educated mothers paid more attention to the development of inde-pendence of their children, they kept trying to find information about child development. They did not want if their children were always troublesome and dependent on others. They tried to train and optimized the development of independence in their children. So the higher the level of mother education, the higher the independence of the child.

\section{Effect of paternal education level on preschooler's independence}

Education level is one of the factors that can affect one's learning process. The higher the level of education a person is, so the more easily the person is receiving information and the higher the ability possessed, and accompanied by knowledge and skills that are not necessarily owned by others. A highly educated person tends to be oriented to preventive measures, more knowledgeable about education, health and development issues. A highly educated person can understand the reality that is happening to society and can contribute according to his ability. As in parenting, highly educated parents will pay more attention to the independence of their children, so that children have high independence (Soetjiningsih and Ranuh, 2013). 
Based on the path analysis results, this study indicated that, there was a direct positive influence and statistically significant between the level of education father and independence of children. But there was also a statistically significant indirect and statistically significant influence between the father's level of self-reliance through the Play Group.

According to Septiari (2012), father's education level can affect the independence of children. Highly educated fathers are more concerned about the development of their children, then father always tries to find out how to make his son has high independence. So the highly educated father has a more independent child. Dad will also work hard for his son to be a child whose hashigh independence by including in early childhood education, such as play groups. Because through the play group, the child can get stimulation of development and practice independently.

The study results were in line with Cvencek et al., (2016) that highly educated fathers have more independent children. Highly educated fathers will pay more attention to the development of their children's independence, they always try to train the children to become children who have high independence, because they do not want if his son is always troublesome and always dependent on others. So the higher the level of education father, the higher the level of independence of children.

\section{Effect of children age on pre- schooler's independence}

Childhood is a congenital factor that is closely related to the development of children, because at every age's phase, the child has certain characteristics that are more prominent than the other characteristics. Preschoolers have various developmental tasks that must be fulfilled such as physical skills, basic skills, attitudes, socializing with peers, forming the concept of everyday life, seeking self-identity, moral values and social values (Herlina, 2013).

Based on the path analysis results, there were direct positive effects and statistically significant between the age of the child and the independence of children. There was an indirectly statistically significant and statistically significant influence between the child's age and the child's independence through the Play Group.

According to Sooter (2013), the age of the child becomes one of the determinants of children's independence, because the older the child's age is the more mature the thoughts are and actions taken by the child, so they will be more independent in facing their daily activities both at home and at school. The earliest years of life are most important in the formation of the child's intelligence, personality, and social behavior ie a year before entering kindergarten. If the age of the child has entered the preschool period, the child tends to attend in PAUD or Play Group so that children get the stimulation of development, namely social and emotional development of children, such as child's independence. Thus, older children have high independence for joining the Play Group.

The study results were in line with the study conducted by Sooter (2013) that there was a positive and statistically significant influence between the age of the child and the independence of the children. The older the child's age is, the child has higher independence, because age is one of the internal factors that affect the independence of children. The most vulnerable age is the toddler age, especially at the first year of age, because it is the basis for the formation of the child's personality, so that period requires special attention so that 
Journal of Maternal and Child Health (2017), 2(4): 284-296

https://doi.org/10.26911/thejmch.2017.02.04.01

aspects of child development can be fulfilled optimally, especially aspects of children's independence.

\section{Influence of play groups on preschooler's independence}

Play Group is one of the educational institutions that teaches how to socialize with peers, the environment, and seeks to develop the potential of the child. Play Group is as the main foundation of education that facilitates the growth and development of children that emphasizes on all aspects of personality development, such as child self-reliance. Therefore, it is necessary for having the stimulation to develop this aspect of development, because the Play Group seeks to create the next generation of quality and optimize the development of children according to the stage of development, so that children have optimal readiness when entering primary education and facing life in adulthood (Cevher-Kalburan, 2014; Lindawati, 2013).

Based on the results of path analysis in this study, it showed that there was a direct positive and statistically significant influence between the Play Group and the independence of preschoolers. Play Group has a positive influence on the development of children independence, because in the play group, children are trained to be more independent, get stimulation of development according to age, stage of development and ability of children, and children have the opportunity to develop their potential. So if the children join the Play Group then they will have a high independence (Sooter, 2013).

The study results were in line with Anderson et al., (2013); Loomans (2014); and Cvencek et al., (2016) explaining that there was a significant and significant influence between the Play Group and child's independence. Preschoolers are assets that have talents, interests, and potentials that need to be developed by those responsible for them in an affection and richly stimulating environment, such as early childhood education. One of PAUD that seeks to optimize the development of children is the Play Group. In the Play Group, children are educated based on theirage and stage of development and learn to socialize with peers. Through the interaction, children will be motivated and have the desire to compete, have confidence, responsibility, take the initiative to solve problems encountered, and try not always depending on others. The Play Group also applies appropriate communication to the child's developmental stage, provides opportunities and confidence in the child, trains the child to be disciplined, responsible and apply good habits according to the age and stages of child development, as this may affect the child's independence. So the children who join the Play Group have high independence.

\begin{tabular}{l}
\hline REFERENCE \\
\hline Ambarwati ER, Yahya AP, Susanto AV \\
(2014). Tingkat Pengetahuan Ibu \\
tentang Stimulasi Tumbuh Kembang \\
dengan Perkembangan pada Anak. \\
Jurnal Kesehatan Samodra Ilmu 5 \\
(2): 94-99. \\
Anderson LM, Shinn C, Fullilove MT, \\
Scrimshaw SC, Fielding JE, Normand, \\
J, CarandeVG (2013). The Effective- \\
ness of Early Childhood Development \\
Programs. American Journal of Pre- \\
ventive Medicine 24 (3): 32-46. \\
Andriani L, Sutiman, Wulandari W (2012). \\
Pengembangan Kemandirian Anak \\
TK Kelompok A melalui Kegiatan \\
Makan Bersama di TK PKK 76 \\
Guwosari Bantul. Jurnal Pendidikan \\
Anak 1 (2): 172-187. \\
Bukaliya R, Mapuranga B (2015). Assessing \\
the Effects of Child Rearing Practices
\end{tabular}


on the Academic Performance of Primary School Learners: A Perspective from the Teachers, Parents and Learners. International Journal of Study in Humanities and Social Studies 2 (2): 13-25.

Cevher-Kalburan N (2014). Early Childhood Pre-Service Teachers Concerns and Solution to Overcome them (The Case of Pamukkale University). South African Journal of Education 34 (1): 118.

Chemagosi MJ, Odongo BC, AlokaPJ (2016). Influence of Parenting Style on Involvement in the Education of Public Preschool Learners in Nandi Central Sub County, Nandi County, Kenya. International Journal of Education and Study 4(1): 137-154.

Chowdhury S, Mitra M (2015). Parenting Style and Altruistic Behavior of Adolescents Life. Journal of Study in Humanities and Social Science 3(6): 20-24.

Cvencek D, Greenwald AG, Meltzoff AN (2016). Implicit Measures for Preschool Children Confirm SelfEsteem's Role in Maintaining a Balanced Identity. Journal of Experimental Social Psychology 62: 50-57.

Dahl GB, Lochner L (2012). The Impact of Family Income on Child Achievement: Evidence from the Earned Income Tax Credit. American Economic Review, 102(5): 1927-1956.

Desmita (2015). Psikologi Perkembangan. Bandung: Remaja Rosdakarya, 126145 .

Dewanggi M, Hastuti D, HernawatiN (2012). Pengasuhan Orangtua dan Kemandirian Anak Usia 3-5 Tahun Berdasarkan Gender di Kampung Adat Urug. Jurnal Ilmu Keluarga dan Konsumen 5 (1): 19-28.
Hajiyar HF, Rezaei T (2014). The Role of Parents' Rearing Behaviors and Parenting Styles in Student's Shyness. Razavi International Journal Medical 2 (3): 1-5.

Hasnain N, Faraz B, AdlakhaP (2013). SelfEsteem and Happiness of Children and Mothers of Different Parental Authority. The International Journal of Humanities and Social Studies 1 (3): 1-6.

Herlina (2013). Hubungan Pola Asuh Keluarga dengan Kemandirian Perawatan Diri Anak Usia Sekolah di Kelurahan Cisalak Pasar Kecamatan Cimanggis Kota Depok. Tesis. Fakultas Ilmu Keperawatan Program Studi Magister Ilmu Keperawatan Universitas Indonesia, Jakarta.

Kamilah (2015). Hubungan Pola Asuh dengan Perkembangan Anak Usia 1-3 Tahun di Puskesmas Jatinegara Jakarta Timur. Jurnal Ilmu Keperawatan Indonesia 5 (1): 33-39.

Kayode OP, Olaronke KB (2014). Perceived Importance of ICT in Preparing Early Childhood Education Teachers for the New Generation Children. International Journal of Evaluation and Study in Education (IJERE) 3 (2): 119-124.

Konnie MM, Alfred K (2013). Influence of Parenting Styles on the Social Development of Children. Academic Journal of Interdisciplinary Studies 2 (3): 123-129.

Lindawati (2013). Faktor-faktor yang Berhubungan dengan Perkembangan Anak Usia Prasekolah. Jurnal Health Quality 4 (1): 22-27.

Loomans MG (2014). Parent Involvement That Supports Children Academically and Promotes the Development of Independence. International Journal of Higher Education 2 (4): 205-213. 
Mardliyah U, Yugistyowati A, ApriliaV (2014). Pola Asuh Orangtua sebagai Faktor Penentu Kualitas Pemenuhan Kebutuhan Dasar Personal Hygiene Anak Usia 6-12 Tahun. Jurnal Ners dan Kebidanan Indonesia 2(2): 86-92.

Mehrinejad SA, Rajabimoghadam S, Tarsafi $M$ (2015). The Relationship between Parenting Styles and Creativity and the Predictability of Creativity by Parenting Styles. Social and Behavioral Sciences 205: 56-60.

Niaraki FR, Rahimi H (2013). The Impact of Authoritative, Permissive and Authoritarian Behavior of Parents on Self-Concept, Psychological Health and Life Quality. European Online Journal of Natural and Social Sciences 2 (1): 78-85.

Niez CC, Alico JC (2015). Relationship of Parenting Styles to Pre-schoolers SocioEmotional Competence and Academic Performance. International Journal of Innovation and Studyin Educational Sciences 2(3): 246-252.

Raya AF, Ruiz-Olivares R, Pino MJ, Herruzo J (2013). A Review about Parenting Style and Parenting Practi- ces and Their Consequences in Disabled and Non Disabled Chidren. International Journal of Higher Education 2(4): 205-213.

Septiari BB (2012). Mencetak Balita Cerdas dan Pola Asuh Orangtua. Yogyakarta: Nuha Medika, 163-174.

Seth M, Ghormode K (2013). The Impact of Authoritative Parenting Style on Educational Performance of Learners at Kindergarten in India. Internasional Study Journal of Social Sciences 2 (10): 1-6.

Setyaningrum SR, Triyanti, Indrawani YM (2014). Pembelajaran di Pendidikan Anak Usia Dini dengan Perkembangan Anak. Jurnal Kesehatan Masyarakat Nasional 8 (6): 243-249.

Soetjiningsih, Ranuh ING (2013). Tumbuh Kembang Anak Edisi 2. Jakarta: EGC.

Sooter T (2013). Early Childhood Education in Nigeria: Issues and Problems. Journal of Educational and Social Study 3 (5): 173-179.

Sunarty K, Dirawan GD (2015). Development Parenting Model to Increase the Independence of Children. International Education Studies 8 (10): 107-113. 